\title{
Effect of Planting Date and Peanut Cultivar on Epidemics of Late Leaf Spot in Georgia
}

\author{
Brian S. Jordan, Albert K. Culbreath, ${ }^{\dagger}$ Timothy B. Brenneman, Robert C. Kemerait Jr., and Katherine L. Stevenson \\ Department of Plant Pathology, The University of Georgia, Tifton, GA 31793-5766
}

\begin{abstract}
Field trials were conducted in 2015 and 2016 in Tifton, GA to determine the effects of planting dates (24 and 27 April, 4, 11, 19, and 26 May 2015; and 11, 18, and 25 April and 2, 9, and 16 May 2016), peanut (Arachis hypogaea) cultivar (Georgia-06G and Georgia-12Y), and seed treatment (nontreated and treated with azoxystrobin, fludioxonil, and mefenoxam) on epidemics of late leaf spot (Nothopassalora personata), plant populations, and peanut yield. Final severity and AUDPC of late leaf spot increased with

populations for the 27 April and 4 May planting dates in 2015 and across all other treatments in 2016. Yields were higher for Georgia-12Y than for Georgia-06G in both years. In 2015, yields of both cultivars decreased according to linear functions of day of year of planting date, but there was no effect of planting date on yield in 2016. The combination of early planting with Georgia-12Y shows potential utility for management of leaf spot in situations such as organic production where fungicide use is minimal.
\end{abstract} later planting dates in both years. For most planting dates in 2015 and the final planting date in 2016, final leaf spot severity and AUDPC were lower for Georgia-12Y than for Georgia-06G. Seed treatment increased plant
Keywords: Nothopassalora personata, Cercosporidium personatum, vigor, organic production
Early leaf spot and late leaf spot, caused by Passalora arachidicola (Hori) U. Braun (syn. Cercospora arachidicola (S. Hori)) and Nothopassalora personata (Berk. \& M.A. Curtis) U. Braun, C. Nakash., Videira \& Crous (syn. Cercosporidium personatum (Berk. $\&$ M.A. Curtis) Deighton), respectively, are among the most common and destructive diseases of peanut (Arachis hypogaea L.) worldwide. If not managed, either disease or the combination of the two can cause complete defoliation, death of the plant, and losses of yield of $75 \%$ or greater (Shokes and Culbreath 1997).

Control of leaf spot diseases in peanut in Georgia is heavily dependent on fungicides (Kemerait et al. 2016). Although numerous fungicides are available that can provide adequate leaf spot control in conventional production, few effective products are available that can be used in organic production (Cantonwine et al. 2008). Cultivars that have high yield potential and resistance or tolerance to leaf spot diseases would be of benefit to both conventional and organic production systems. Georgia-12Y (Branch 2013) is a cultivar with some apparent tolerance to late leaf spot (Branch and Culbreath 2013; Jordan et al. 2017). Although it has only a low level of field resistance compared with the standard susceptible cultivar Georgia-06G, it produced excellent yield without fungicide application (Branch and Culbreath 2013; Jordan et al. 2017) and may have potential for use in organic production.

Cultural practices such as choice of planting date can affect leaf spot epidemics. In the southeastern United States, earlier planting dates may allow avoidance of leaf spot inoculum and resultant epidemics. Sanden et al. (1981) reported that fewer leaf spot lesions and less defoliation caused by leaf spot were associated with the earlier planting dates (22 and 25 April), and later planting dates (21 and

${ }^{\dagger}$ Corresponding author: A. K. Culbreath; spotwilt@uga.edu

Funding: This work was supported by the USDA National Institute of Food and Agriculture, Hatch project GEO-691. Support for this research was also funded in part by the National Peanut Board, the Georgia Agricultural Commodity Commission for Peanuts, and Georgia Foundation Seed.

The $\boldsymbol{e}$-Xtra logo stands for "electronic extra" and indicates that one supplementary table is published online.

Accepted for publication 1 November 2018.

() 2019 The American Phytopathological Society
23 May) were associated with decreased yield due to leaf spot. They did not indicate whether early or late leaf spot was predominant. A similar study by Shokes et al. (1982) found that a late planting date (approximately 23 May) had a sixfold increase in the number of lesions of late leaf spot compared with an earlier planting date. More recently, Fulmer (2017) reported earlier onsets for both early leaf spot and late leaf spot in Georgia-06G planted in May or June than in April. In recent years, there has been little else reported on the effect of planting date on leaf spot. One reason for this is that earlier planting dates often result in more severe epidemics of tomato spotted wilt, caused by tomato spotted wilt virus (TSWV) (Brown et al. 2005; Culbreath and Srinivasan 2011; Culbreath et al. 2003, 2010). Mid- to late May planting dates typically have a much lower risk of tomato spotted wilt than earlier planting dates (Brown et al. 2005; Culbreath et al. 2003). For cultivars with low to moderate levels of field resistance to TSWV, choice of planting dates to minimize risk of losses to tomato spotted wilt was critical for management of this disease (Culbreath and Srinivasan 2011; Culbreath et al. 2010). In the 1990s, primarily because of tomato spotted wilt, there was a dramatic shift from April planting dates to May planting dates (Culbreath et al. 2003). However, availability of cultivars, such as Georgia-06G (Branch 2007) and Georgia-12Y, with higher levels of field resistance to TSWV (Culbreath et al. 2016), may allow planting earlier without increasing the risk of losses to TSWV (Culbreath et al. 2010). Thus, with adequate field resistance to TSWV, early planting combined with moderate levels of resistance or tolerance to leaf spot might provide acceptable levels of leaf spot control in organic production and help reduce the number of fungicide applications needed in conventional production.

Establishment of adequate plant populations with good earlyseason vigor is also a challenge in organic production systems (Cantonwine et al. 2011; Tubbs et al. 2013). In conventional production, use of fungicide seed treatments can greatly improve plant stands compared to those achieved with nontreated seed (Brenneman 2007). However, there are few organically acceptable seed treatments available that provide consistent protection from seed rots and damping off (Cantonwine et al. 2011; Tubbs et al. 2013). Emergence and vigor of most peanut cultivars can be affected greatly by soil temperature (Beasley 2013; Prasad et al. 2006). Planting recommendations in Georgia typically include having soil temperatures of $\geq 18^{\circ} \mathrm{C}$ at the 10 -cm soil depth for three consecutive days prior to planting peanuts (Beasley 2013). In the southeastern United States, earlier planting dates (before 1 May) typically are associated with 
lower soil temperatures than later planting dates. Therefore, using earlier planting dates to escape leaf spot epidemics will likely make stand establishment more challenging, especially if effective seed treatments are not available. Cultivars that tolerate cooler temperatures would be desirable for use with earlier planting dates. Similarly, cultivars with resistance to prominent damping off pathogens or that are vigorous enough to escape damage by the pathogens would be desirable for both conventional and organic production. As with planting date, stand establishment can be critical for managing tomato spotted wilt, with sparse and/or uneven stands at greater risk to losses to spotted wilt (Brown et al. 2005; Culbreath and Srinivasan 2011; Culbreath et al. 2003). Observations in previous experiments and in production fields indicated that Georgia-12Y has potential to improve stand establishment efficiency and reduce time until row middles are covered compared with the predominant cultivar Georgia-06G (Branch and Culbreath 2013; Jordan et al. 2017; Plumblee et al. 2018).

The primary objectives of this study were to determine the effects of planting date on leaf spot epidemics and yield in Georgia-12Y and the standard cultivar Georgia-06G, with particular emphasis on whether use of early planting dates might allow avoidance of severe leaf spot epidemics. A secondary objective of this study was to determine the effect of cultivar and planting date on stand establishment and early-season vigor for nontreated seed compared with seed treated with conventional fungicides.

\section{Materials and Methods}

Treatments and experimental design. Field experiments were conducted in 2015 and 2016 at the University of Georgia Coastal Plain Experiment Station. Trials were conducted in separate fields at the Lang-Rigdon Farm (latitude 31.516; longitude -83.546 in 2015 , and latitude 31.520 ; longitude -83.546 in 2016). The soil type in both fields was a Tifton sandy loam (fine sandy, siliceous thermic Plinthic Paleudult). Both fields had a history of moderate to heavy infestations of $P$. arachidicola or $N$. personata in previous years when peanut was grown. Each field had been planted to cotton (Gossypium hirsutum) the year preceding the trial and peanut 2 years before the trial.

A randomized complete block design was used in both years. Treatments consisted of two cultivars, Georgia-06G and Georgia$12 \mathrm{Y}$, two seed treatments (seed treated with azoxystrobin $0.128 \mathrm{~g} / \mathrm{kg}$ of seed, fludioxonil $0.008 \mathrm{~g} / \mathrm{kg}$ of seed, and mefenoxam $0.0016 \mathrm{~g} / \mathrm{kg}$ of seed, applied as Dynasty PD [Syngenta Crop Protection, Greensboro, NC] and nontreated seed), and six planting dates in a $2 \times 2 \times 6$ factorial arrangement. Planting dates for both years are shown in
Table 1. Initial planting dates were planned for the second week of April in both years. However, in 2015, due to weather and wet soil, initial planting was later than planned. Each treatment combination was replicated four times in both years. Plot length was $9.2 \mathrm{~m}$ in 2015 and $6.7 \mathrm{~m}$ in 2016 . Plots were $1.8 \mathrm{~m}$ wide with two rows $0.9 \mathrm{~m}$ apart. Seed was planted at $14.8 \mathrm{seed} / \mathrm{m}$ of row at a depth of $4 \mathrm{~cm}$.

Plant population and vigor assessment. Early-season withinrow plant densities were calculated by counting emerged plants in two arbitrarily selected $3-\mathrm{m}$ sections of row in each plot. The two count totals were then divided by $3 \mathrm{~m}$ and averaged to obtain a mean plant density estimate for each plot. Plant density was measured 14 days after planting (DAP) for each respective planting date in both years. Plant canopy width was recorded as a quantitative measure of plant vigor. Width of the canopy was measured as the distance between the outermost tips of the lateral branches on opposite sides of the row. Width was measured at six arbitrarily chosen locations within each plot. Measurements were made 56 DAP for each planting date in both years. The mean of the six measurements of canopy width was recorded for each plot. Canopy width measurements did not include portions of the row where there were no plants.

Environmental measurements. Soil temperatures were obtained from the University of Georgia Automated Environmental Monitoring Network (http://www.georgiaweather.net/) from a monitoring station approximately $3.1 \mathrm{~km}$ from the Lang-Rigdon Farm (latitude 31.494; longitude -83.526). Daily rainfall and irrigation amounts were recorded for the months of April through October in both years.

Disease assessment. Leaf spot severity was assessed visually using the ordinal Florida 1-10 leaf spot scale where $1=$ no disease, $0 \%$ defoliation, and $10=100 \%$ defoliation with plants dead, killed by leaf spot (Chiteka et al. 1988). Leaf spot ratings were made within each planting date at $90,97,104,111,118,126,133$, and 140 DAP in 2015 and 90, 97 105, 112, 119, 126, 133, and 140 DAP in 2016. The area under the disease progress curve was calculated for each plot as described by Shaner and Finney (1977) using Florida 1-10 scale ratings. At each evaluation, a minimum of 20 arbitrarily chosen leaves with spots were examined to determine whether early leaf spot or late leaf spot was predominant. Lesions that were dark brown to black on the abaxial surface with sporulation were indicative of late leaf spot, lesions that were lighter brown on the abaxial surface with sporulation on the adaxial surface were indicative or early leaf spot (Shokes and Culbreath 1997). To ensure that the ratings represented defoliation caused by leaf spot, plots were also examined for presence of peanut rust (Puccinia arachidis) and Choanephora leaf spot, caused by Choanephora spp.

Table 1. Dates of planting, average soil temperatures before planting, dates digging, and dates of harvest of Georgia-06G and Georgia-12Y peanut cultivars, University of Georgia Lang-Rigdon Farm, Tifton, 2015-2016

\begin{tabular}{|c|c|c|c|c|c|}
\hline \multirow[b]{2}{*}{ Planting date ${ }^{a}$} & \multirow[b]{2}{*}{ Soil temperature $\left({ }^{\circ} \mathrm{C}\right)^{\mathrm{b}}$} & \multicolumn{2}{|c|}{ Georgia-06G } & \multicolumn{2}{|c|}{ Georgia-12Y } \\
\hline & & Digging date & Harvest date & Digging date & Harvest date \\
\hline \multicolumn{6}{|l|}{2015} \\
\hline 24 April $(114)^{\mathrm{c}}$ & 20.6 & 7 September $(250)^{\mathrm{c}}$ & 14 September $(260)^{\mathrm{c}}$ & 16 September $(259)^{\mathrm{c}}$ & 22 September $(265)^{c}$ \\
\hline 27 April (117) & 24.2 & 10 September (253) & 17 September (263) & 19 September (262) & 26 September (269) \\
\hline 4 May (124) & 20.0 & 17 September (260) & 23 September (266) & 26 September (269) & 3 October (273) \\
\hline 11 May (131) & 25.3 & 24 September (267) & 1 October (274) & 3 October (276) & 10 October (283) \\
\hline 19 May (139) & 27.8 & 2 October (275) & 9 October (282) & 11 October (284) & 21 October (294) \\
\hline 26 May (146) & 29.2 & 9 October (282) & 16 October (289) & 18 October (291) & 2 November (306) \\
\hline \multicolumn{6}{|l|}{2016} \\
\hline 11 April (101) & 18.8 & 24 August (236) & 29 August (241) & 3 September (246) & 13 September (256) \\
\hline 18 April (108) & 16.2 & 31 August (243) & 7 September (250) & 10 September (253) & 20 September (263) \\
\hline 25 April (115) & 21.6 & 7 September (250) & 13 September (256) & 17 September (260) & 26 September (269) \\
\hline 2 May (122) & 27.2 & 14 September (257) & 20 September (262) & 24 September (267) & 6 October (279) \\
\hline 9 May (129) & 23.6 & 21 September (264) & 26 September (269) & 1 October (274) & 13 October (286) \\
\hline 16 May (136) & 27.4 & 28 September (271) & 13 October (286) & 8 October (281) & 19 October (292) \\
\hline
\end{tabular}

a Planting date was the same for both cultivars. Planting dates prior to 1 May are considered early. Planting dates from 1 May to 20 May are mid, and planting dates after 20 May are considered late.

${ }^{\mathrm{b}}$ Average soil temperature at $10.2 \mathrm{~cm}$ depth for the 6 days preceding the respective planting dates as recorded at a University of Georgia Automated Environmental Monitoring Network station approximately $3.1 \mathrm{~km}$ from the field site.

${ }^{\mathrm{c}}$ Numbers in parentheses are ordinal days of the year for the standard calendar dates. 
Incidence of tomato spotted wilt was evaluated within each planting date at 98 DAP in 2015 and 91 DAP in 2016. Incidence was determined by counting the number of $0.3 \mathrm{~m}$ portions of row containing plants severely stunted, chlorotic, wilted, or killed by TSWV for each plot and converting that number to a percentage of total row length (Culbreath et al. 1997).

Immediately after plots were inverted for harvest, plants were examined for damage from stem rot, caused by Sclerotium rolfsii (Sacc.). Incidence of stem rot was determined by counting the number of $0.3-\mathrm{m}$ portions of row with symptoms of the disease or signs of $S$. rolfsii (Rodriguez-Kabana et al. 1975). The number of affected 0.3-m portions of row was converted to a percentage of total row length.

Harvest and yield assessments. Plots of Georgia-06G were dug and inverted 136 DAP in 2015 and 135 DAP in 2016 (Table 1). Plots of Georgia-12Y were dug and inverted 145 DAP in both years. In all cases except for the last planting date for Georgia-12Y in 2015, inverted plants were allowed to dry in the field 7 to 11 days. For the last planting date for Georgia-12Y in 2015, harvest was delayed due to wet conditions in the field. The plants were inverted on time, but remained in the field for 15 days before being harvested (Table 1). Peanut pods were harvested mechanically. Pod yields were determined by weighing harvested pods after they were dried and adjusted to $10 \%$ (wt/wt) moisture.

Data analysis. Data were analyzed using SAS v.9.4 software (SAS Institute, Cary, NC). For row canopy width, plant population, incidence of spotted wilt, AUDPC for leaf spot, incidence of stem rot, and yield, a linear mixed models procedure was used with maximum likelihood estimation of variance components (Proc Mixed). The Satterthwaite method was used for computing the denominator degrees of freedom ("ddfm=satterth" in the model statement). Since planting dates differed in the 2 years, experiments were analyzed separately.

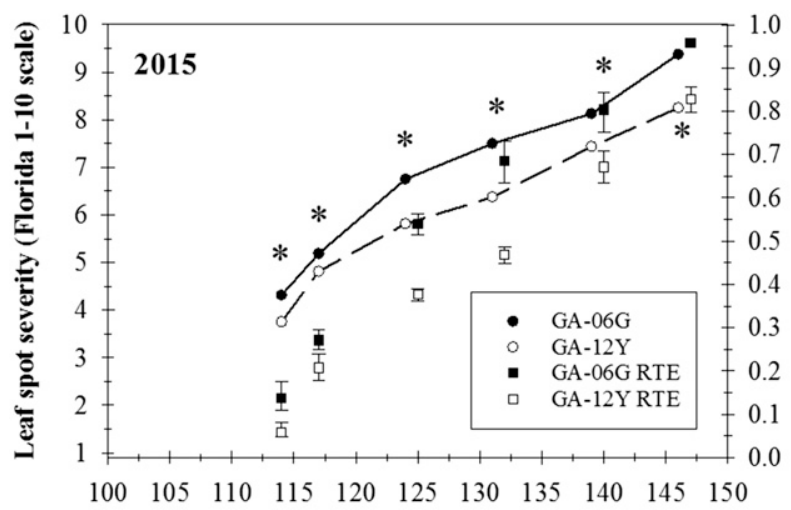



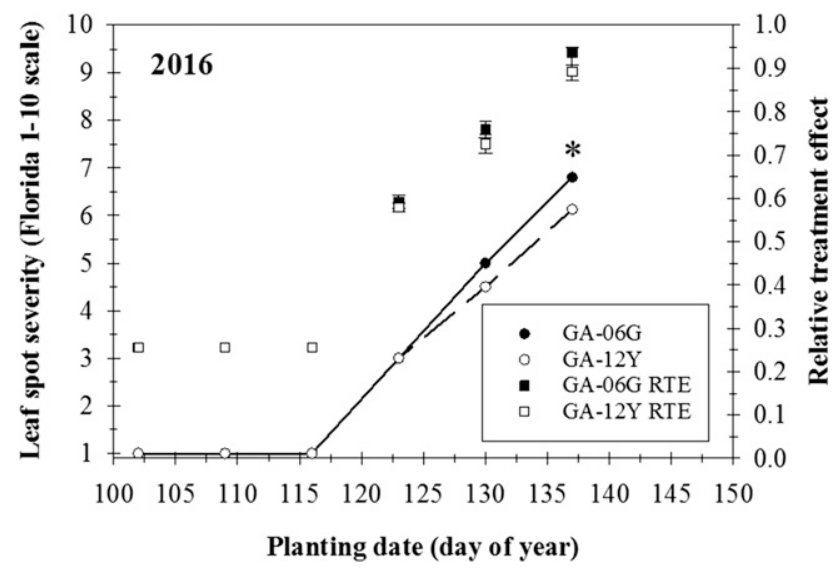

Fig. 1. Effects of planting date and Georgia-06G (GA-06G) (solid line) and Georgia$12 Y(G A-12 Y)$ (dashed line) cultivars on final severity of late leaf spot in peanut. Median disease severity ratings and estimated relative treatment effects (RTE) presented are pooled across seed treatments. Error bars for RTEs represent the $95 \%$ confidence intervals for each RTE. An asterisk indicates that final leaf spot severity differed for the two cultivars on that planting date based on RTEs and their respective $95 \%$ confidence intervals.
Cultivar, seed treatment, and planting date were considered fixed effects, whereas block was considered a random effect. Effects were considered significant when $P \leq 0.05$. Fisher's least significant difference (LSD) values were computed using standard errors and $t$ values of adjusted degrees of freedom from the pdiff option in Proc Mixed. Regression analysis (Proc GLM) was used to examine the relationship between these variables and DOY values. Harvest was delayed for the last planting date for Georgia-12Y in 2015; therefore, yield for Georgia-12Y for that planting date was not included in the regression of yield on planting date DOY. Regression was conducted separately for the two cultivars.

Since final leaf spot severity was evaluated using an ordinal scale that does not represent a continuous scale, final leaf spot severity ratings from both years were analyzed nonparametrically based on ranks using Proc Mixed (Shah and Madden 2004). Relative treatment effects and their respective $95 \%$ confidence intervals were calculated using the LD CI macro for SAS (Brunner et al. 2002; Shah and Madden 2004), and were used to discern differences among treatments. Relative treatment effect $\left(\hat{p}_{i}\right)$ was estimated from the mean ranks according to:

$$
\hat{p}_{i}=\frac{1}{N}\left(\bar{R}_{i j k} \cdot-\frac{1}{2}\right)
$$

where $\bar{R}_{i j k}$. is the mean rank for the treatment among all observations $(N)$. Relative treatment effects have a range of 0 to 1.0. Two relative treatment effects were considered different if the confidence intervals did not overlap.

\section{Results}

Environmental conditions. The average soil temperatures for 6 days preceding the respective planting dates are shown in Table 1. Monthly rainfall and irrigation totals for the two seasons are provided in Supplementary Table S1.

Final leaf spot severity and AUDPC. Late leaf spot was the predominant foliar disease in both years, and represented $>95 \%$ of the leaf spots based on visual estimates No other foliar fungal disease was observed. Leaf spot epidemics began earlier and were more severe in 2015 than in 2016 (data not shown). In 2015, cultivar $(P<0.001)$, planting date $(P<0.001)$, and cultivar $\times$ planting date $(P=0.015)$ had significant effects on final leaf spot severity, but no other main effect or interaction was significant $(P \geq 0.23)$. Relative treatment effects for leaf spot ratings for Georgia-12Y were lower than those of Georgia06G across all planting dates (Fig. 1). Final leaf spot ratings for both cultivars increased with each successive planting date (Fig. 1).

In 2015, cultivar $(P<0.0001)$, planting date $(P<0.0001)$, and cultivar $\times$ planting date $(P=0.025)$ had significant effects on AUDPC, but no other main effect or interaction was significant $(P \geq 0.38)$. AUDPC of each cultivar increased linearly with successive planting dates (Fig. 2).

In 2016, cultivar $(P=0.015)$ and planting date $(P<0.0001)$ had significant effects on leaf spot severity, but no other main effect or interaction was significant $(P \geq 0.15)$. No leaf spot was observed in either cultivar for the first three planting dates. Across other factors, relative treatment effects on final leaf spot severity were similar for Georgia-06G and Georgia-12Y for all except the final planting date, where leaf spot severity was higher for Georgia-06G than for Georgia-12Y (Fig. 1). After the third planting date, final leaf spot severity in both cultivars increased with each successive planting date (Fig. 1).

In 2016, cultivar $(P=0.0009)$, planting date $(P<0.0001)$, and cultivar $\times$ planting date $(P<0.0001)$ had significant effects on AUDPC, but no other main effects or interactions were significant $(P>0.23)$. No leaf spot occurred in the first three planting dates (Fig. 2); the first two were omitted from the regression analysis. After the third planting date, AUDPC values within each cultivar increased according to quadratic functions of planting date (Fig. 2).

Tomato spotted wilt and stem rot. Final incidence of tomato spotted wilt was $<10 \%$ in both years, but differed significantly among treatments. In 2015 , cultivar $(P<0.0001)$ and planting date $(P=$ $0.011)$ had significant effects on final incidence of tomato spotted wilt, but no other main effect or interaction was significant. Across 
other factors, final incidence of tomato spotted wilt was $7.6 \%$ and $2.8 \%$ in Georgia-06G and Georgia-12Y, respectively $(\mathrm{LSD}=0.8$, $P=0.05)$. Across other factors, incidence of tomato spotted wilt decreased linearly with successive planting dates (Fig. 3).

In 2016, cultivar $(P=0.004)$ and planting date $(P=0.039)$ had significant effects on incidence of tomato spotted wilt, but no other main effect or interaction effect was significant $(P>0.05)$. Across other treatment factors, final incidence of tomato spotted wilt was $4.2 \%$ and $1.6 \%$ (LSD $=0.5, P=0.05$ ) for Georgia-06G and Georgia$12 \mathrm{Y}$, respectively. There was no significant linear or quadratic relationship between final incidence of spotted wilt and planting date. Across other treatment factors, final incidence of spotted wilt was higher in peanuts planted on the second or third planting date than in peanuts planted on either of the last two planting dates (Fig. 3). Incidence of stem rot was low $(<8 \%)$ across treatments in both years. There were no significant treatment main effects or interactions on stem rot incidence in either year (data not reported).

Plant population. In 2015, cultivar $(P<0.0001)$, seed treatment $(P=$ $0.033)$, planting date $(P<0.0001)$, planting date $\times$ cultivar $(P=0.03)$, and planting date $\times$ seed treatment $(P<0.0001)$ effects were significant for plant population. However, cultivar $\times$ seed treatment, and cultivar $\times$ seed treatment $\times$ planting date were not significant $(P>0.71)$. Across seed treatments, plant densities were greater for Georgia-12Y than Georgia-06G for the DOY 117 and 124 planting dates, but populations were similar for the cultivars for all other planting dates (Table 2). Georgia-06G plant densities were lowest for the DOY 117 and 124 planting dates (Table 2), and were highest for the DOY 146 planting
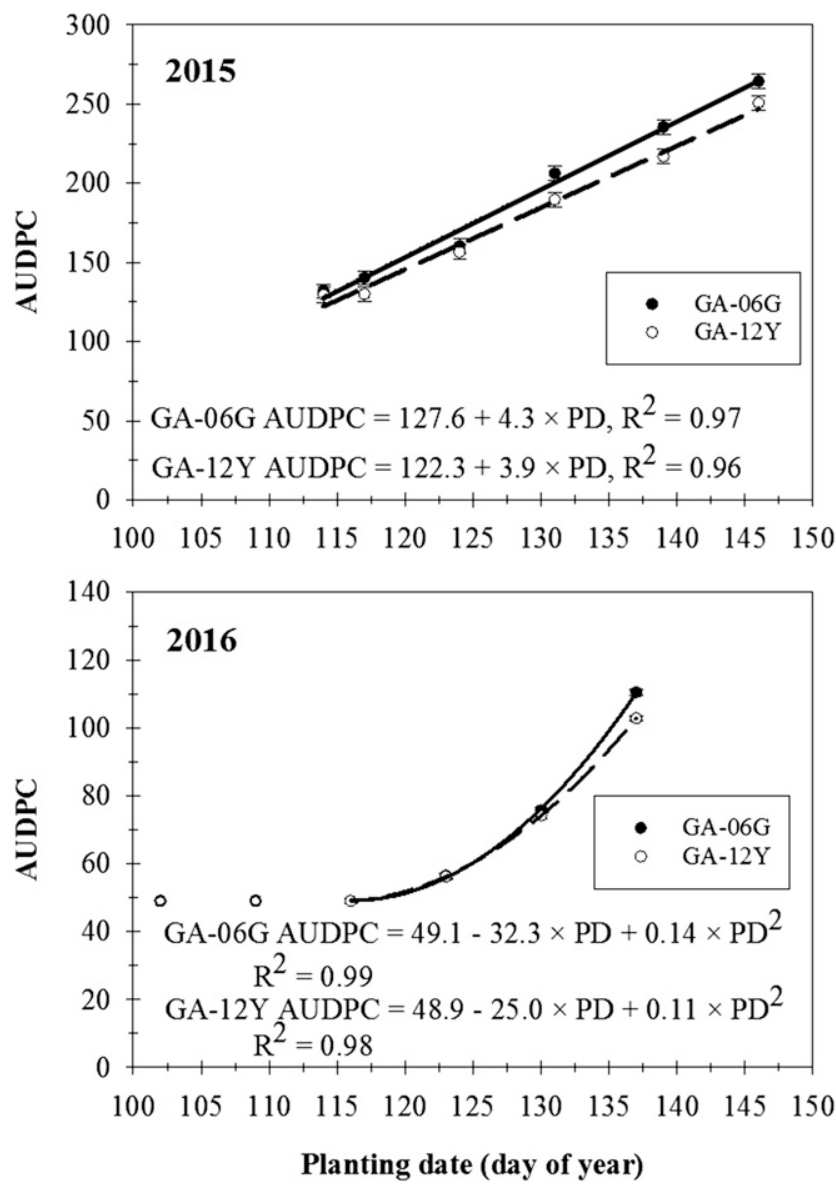

Fig. 2. Effects of planting date and Georgia-06G (GA-06G) (solid line) and Georgia$12 Y(G A-12 Y)$ (dashed line) cultivars on area under the disease progress curve (AUDPC) for late leaf spot of peanut. Means presented are pooled across seed treatments. Error bars represent standard errors of the means. Intercept values for regression of AUDPC on planting date (PD) are the day of year for initial planting date in 2015 and the third planting date in 2016. Since no leaf spot was observed for the first three planting dates in 2016, data from the first two planting dates was omitted from the regression analysis. date (Table 2). Plant densities for Georgia-12Y were lowest at the DOY 117 planting date (Table 2). Plant densities were higher for the last three planting dates than for any of the earlier planting dates, and densities did not differ among the last three planting dates (Table 2).

Across cultivars, plant densities were lower for nontreated seed than for those with the standard seed treatment at the DOY 117 and 124 planting dates, but densities did not differ between the treatments for any other planting date (Table 2). Plant populations for nontreated seed were lowest for the DOY 117 planting date (Table 2). Plant populations for the standard seed treatment did not differ among the first three planting dates. Within each of the seed treatments, plant densities were higher for the last three planting dates than any earlier planting date, and plant densities did not differ among the last three planting dates (Table 2).

In 2016, there was a significant effect of seed treatment $(P=$ 0.0006) on plant population. No other main effect or interaction was significant $(P>0.07)$. Across all other factors, plant densities

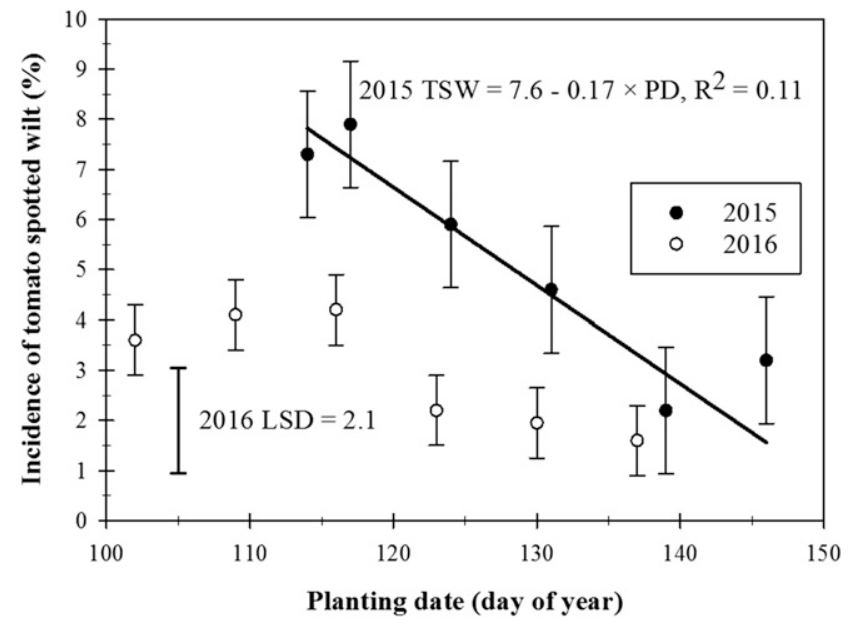

Fig. 3. Effect of planting date (PD) on incidence of tomato spotted wilt in peanut 98 days after planting in 2015 (solid line) and 91 days after planting in 2016. Means presented are pooled across cultivars and seed treatments. Error bars represent standard errors of the means. Intercept value for the regression equation is the day of year for the initial planting date in 2015.

Table 2. Interactive effects of planting date with seed treatment and peanut cultivar on plant population, University of Georgia Lang Farm, Tifton, 2015

\begin{tabular}{lccccc}
\hline & $\begin{array}{c}\text { Plant population by } \\
\text { seed treatment } \\
\text { a,b } \\
\text { (plants/m of row) }\end{array}$ & & \multicolumn{2}{c}{$\begin{array}{c}\text { Plant population by } \\
\text { cultivara,c }\end{array}$ (plants/m of row) } \\
\cline { 2 - 3 } \cline { 5 - 6 } $\begin{array}{l}\text { Planting date } \\
\text { (day of year) }\end{array}$ & Treated $^{\mathbf{d}}$ & Nontreated & & Georgia-06G & Georgia-12Y \\
\hline 24 April (114) & 10.3 & 9.9 & & 9.8 & 10.4 \\
27 April (117) & $10.0^{*}$ & 7.9 & & $8.5^{*}$ & 9.5 \\
4 May (124) & $10.0^{*}$ & 9.1 & & $8.7^{*}$ & 10.5 \\
11 May (131) & 12.1 & 12.6 & & 12.1 & 12.6 \\
19 May (139) & 12.3 & 12.2 & & 12.0 & 12.5 \\
26 May (146) & 12.8 & 12.9 & & 12.9 & 12.8 \\
LSD $(P=0.05)$ & 0.8 & 0.8 & & 0.8 & 0.8 \\
\hline
\end{tabular}

a Plant population (plants $/ \mathrm{m}$ of row) was determined 14 days after planting in each plot.

${ }^{\mathrm{b}}$ There was a significant $(P \leq 0.001)$ interaction of planting date $\times$ seed treatment. Therefore, comparisons of each factor were made within levels of the other factor. An asterisk $(*)$ indicates a significant difference between treated and nontreated seed within a planting date $(\mathrm{LSD}=0.8, P=0.05)$.

${ }^{\mathrm{c}}$ There was a significant $(P=0.03)$ interaction of planting date $\times$ cultivar. Therefore, comparisons of each factor were made within levels of the other factor. An asterisk (*) indicates a significant difference between cultivars within a planting date (LSD $=0.8, P=0.05)$.

${ }^{\mathrm{d}}$ Seeds were treated with a mixture of azoxystrobin $0.128 \mathrm{~g} / \mathrm{kg}$ of seed, fludioxonil $0.008 \mathrm{~g} / \mathrm{kg}$ of seed, and mefenoxam $0.0016 \mathrm{~g} / \mathrm{kg}$ of seed applied as Dynasty PD. 
14 DAP were 10.4 and $10.8 / \mathrm{m}$ of row $(\mathrm{LSD}=0.2, P=0.05$ ) for nontreated and treated seed, respectively.

Vigor assessment. In 2015, cultivar and planting date main effects were significant $(P<0.0001)$ for canopy width, but no other main effect or interaction was significant $(P>0.12)$. Across all other factors, canopy width was $75.5 \mathrm{~cm}$ and $84.3 \mathrm{~cm}(\mathrm{LSD}=1.4, P=0.05)$ for Georgia-06G and Georgia-12Y, respectively. Across other factors, the relationship between canopy width and planting date was described by a quadratic function of ordinal planting date (Fig. 4). In 2016, cultivar $(P<0.001)$, seed treatment $(P=0.05)$, and planting date $(P<0.001)$ main effects were significant, but no interactions were significant $(P>0.46)$. Across other factors, canopy width at 56 DAP was $55.3 \mathrm{~cm}$ and $60.2 \mathrm{~cm}(\mathrm{LSD}=2.2, P=0.05)$ for Georgia-06G and Georgia-12Y, respectively. Across all other treatments, canopy width was $56.5 \mathrm{~cm}$ and $58.9 \mathrm{~cm}(\mathrm{LSD}=2.2, P=$ 0.05 ) for plots with nontreated and treated seed, respectively. Across other factors, canopy width was described by a quadratic function of ordinal planting date (Fig. 4).

Yield. In 2015, cultivar $(P<0.0001)$ and planting date $(P<0.0001)$ had significant effects on yield, but no other main effects or interactions were significant $(P \geq 0.055)$. Across other factors, yield was 5,335 and $5,996 \mathrm{~kg} / \mathrm{ha}(\mathrm{LSD}=319, P=0.05$ ) for Georgia-06G and Georgia-12Y, respectively. Since harvest was delayed for the final planting date for Georgia-12Y, yield for that planting date was not included for that cultivar. Within cultivars, yield decreased according to linear functions of planting date (Fig. 5). In 2016, cultivar had a significant effect $(P<0.0001)$ on yield, but no other main effect or interaction was significant $(P \geq 0.06)$. Across other treatment factors, yield was 3,118 and $4,564 \mathrm{~kg} / \mathrm{ha}$ (LSD $=433, P=$ 0.05 ) for Georgia-06G and Georgia-12Y, respectively.

\section{Discussion}

Planting date effects on late leaf spot observed on Georgia-06G and Georgia-12Y in this study corroborated previous reports on the cultivar Florunner that earlier planting dates reduced severity of leaf spot epidemics (Sanden et al. 1981; Shokes et al. 1982). Shokes et al. (1982) reported that planting in April reduced incidence and severity of leaf spot diseases. Sanden et al. (1981) reported a sixfold increase in the number of leaf spot lesions when peanuts were planted late (21-23 May) versus an early planting date (15-25 April).

The current study was not planned specifically to address only late leaf spot, but there was very little early leaf spot in any plot in either year of this study. Therefore, inference of the results from this study for management of early leaf spot would be speculative. Risk of losses to leaf spot related to planting date has been considered to be similar for early and late leaf spot (Kemerait et al. 2016). Fulmer (2017)

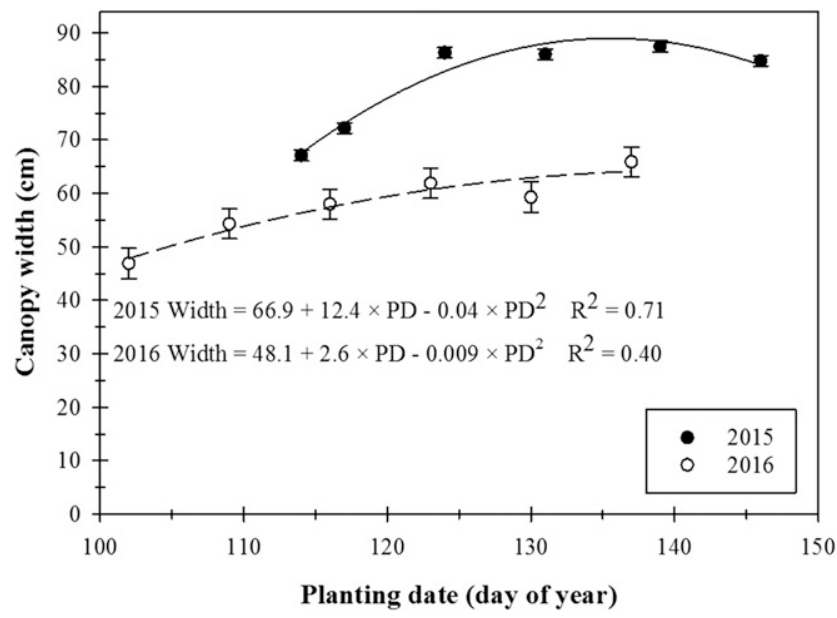

Fig. 4. Effect of planting date (PD) on mean canopy width of peanut plants measured 56 days after planting for 2015 (solid line) and 2016 (dashed line). Means presented are pooled across cultivars and seed treatments. Error bars represent standard errors of the means. Intercept values for regression equations are day of year for the initial planting date within each year. reported that the onset of both early and late leaf spot on Georgia06G tended to be earlier (in days after planting) with later planting dates, even when inoculum was provided. Defoliation at 130 DAP was lower for peanuts planted in late April than for peanuts planted in June, regardless of whether early or late leaf spot was predominant (Fulmer 2017). However, additional information is needed on specific effects of planting date on early leaf spot, especially related to management of this disease on Georgia-12Y.

In 2015, increasing late leaf spot severity as indicated by final leaf spot ratings and AUDPC with later planting dates corresponded with reductions in yield. Although other factors were likely involved, much of the yield reduction was hypothesized to be due to increases in leaf spot severity. In 2016, yields were not as high as in 2015, and there was little response with planting date. The differences in severity of leaf spot epidemics and yields are likely due to differences in environmental conditions between the 2 years. In 2015, conditions during much of the season were favorable for peanut production and development of leaf spot epidemics. However, in 2016 a long period of dry hot conditions may have inhibited normal pollination of the peanut plants (Chu et al. 2016), delayed canopy closure, and delayed and slowed development of the leaf spot epidemics even with irrigation applications. The remnant of hurricane Hermine resulted in heavy rainfall 1-2 September 2016. Plots from the earlier three planting dates that were dug before or shortly after the storm had very little leaf spot compared with those dug and harvester later. These results indicate that the use of early planting dates, especially with a cultivar like Georgia-12Y, has potential for avoiding or minimizing damage by late leaf spot and for producing yield in situations where fungicide use is limited or omitted completely.

However, in addition to leaf spot epidemics, other factors affected by planting date may have significant impact on yield. In 1981 when Sanden et al. performed their research, tomato spotted wilt was not a factor in the southeastern United States. After tomato spotted wilt emerged as a limiting factor to peanut production in the southeastern United States, choice of planting date became a key factor in an integrated regime for management of that disease. In addition, the peanut cultivars used in those earlier studies are no longer grown. Florunner (Norden et al. 1969), the predominant cultivar used when those studies were conducted, is extremely susceptible to TSWV (Culbreath et al. 1992). Until the emergence of tomato spotted wilt as a major problem in the southeastern United States, even the earliest plantings examined in this study would have been common. Later planting dates have been used by growers to avoid early season thrips

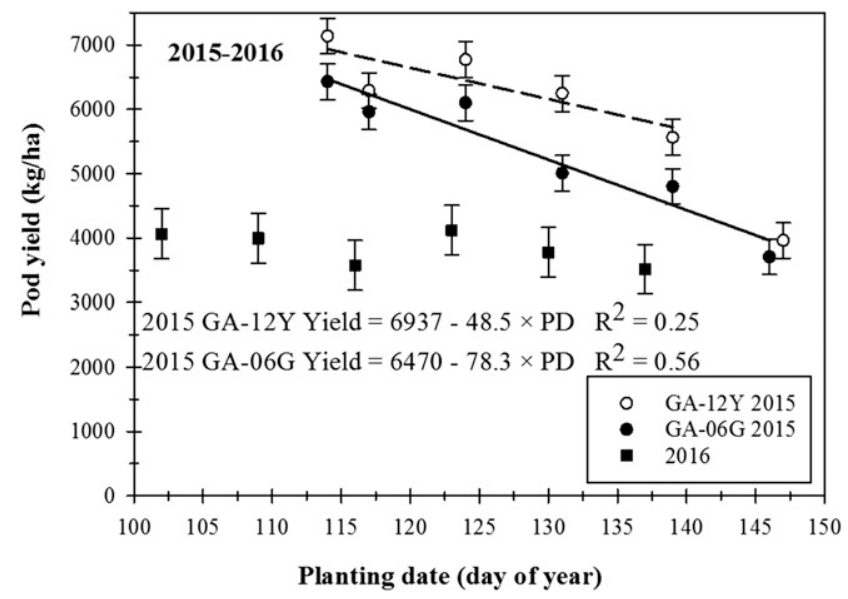

Fig. 5. Effect of planting date (PD) on peanut yield in 2015 and 2016. Means and regression shown for 2015 for Georgia-06G (GA-06G) (solid line) and Georgia-12Y (GA-12Y) (dashed line) pooled across seed treatments. Yield for the final 2015 planting date for Georgia-12Y is shown but was not included in the regression. Means presented for 2016 are pooled across cultivars and seed treatments. Error bars represent standard errors of the means. Intercept values for the regression equations for 2015 are the day of year for the initial planting date. There was no significant $(P>0.05)$ linear or quadratic relationship between planting date and pod yield in 2016. 
pressure and higher risk of losses to tomato spotted wilt (Brown et al. 2005; Culbreath et al. 2003). Culbreath et al. (2010) reported that avoiding early planting dates was important for the cultivar Georgia Green with moderate field resistance to TSWV, but that a cultivar such as AP-3, with greater field resistance to TSWV, could allow more flexibility with planting date. Although epidemics of tomato spotted wilt were not severe in either cultivar in this study, results corroborated previous reports of reduced incidence of tomato spotted wilt with later planting dates (Culbreath et al. 2010) and lower incidence in Georgia-12Y than in Georgia-06G (Culbreath et al. 2016). Georgia-12Y has among the highest level of field resistance to TSWV among currently available cultivars in the southeastern United States (Culbreath et al. 2016).

Adequate stand and early-season vigor are important in both conventional and organic production systems. They can be especially important when no or low fungicide programs are used. Cooler soil temperatures often associated with earlier planting dates can slow emergence of young plants and reduce stands especially when no or less effective fungicide seed treatments are used. Stand establishment and canopy width measurements in Georgia-12Y provided evidence of more rapid canopy closure than Georgia-06G. Results from this study corroborate reports of better early-season vigor (Jordan et al. 2017) and faster canopy closure (Plumblee et al. 2018) in Georgia-12Y than in Georgia-06G. Early canopy closure should help with weed competition in both production systems, and would be especially useful in organic production (Johnson and Mullinex 2008). Earlier canopy closure might also provide environmental conditions that would allow for earlier onset of leaf spot epidemics. This was not addressed in this study. However, if any increase in leaf spot severity occurred in Georgia-12Y due to earlier canopy closure, the increase was not large enough to negate advantages of this cultivar compared with Georgia-06G.

Management of stem rot must also be considered for peanut production in Georgia, but stem rot was not a major factor in this study. Early planted peanut have been shown to have more damage from stem rot (Brenneman and Hadden 1996; Tsai and Brenneman 2018). Georgia-12Y has shown resistance to this disease (Brenneman et al. 2014). However, incidence of stem rot in this study was too low to discern effects of cultivar or planting date. Studies addressing stem rot management suitable for organic production systems are in progress.

Results from this study indicate that an early planting date can be used to reduce severity of late leaf spot epidemics and still provide the yield needed from the organic industry. Based on previous reports (Branch and Culbreath 2013; Jordan et al. 2017) and results from this study, Georgia-12Y shows potential for use in organic production given its combination of resistance or tolerance to multiple diseases, potential for stand establishment without conventional seed treatments, early-season vigor, and yield potential.

\section{Acknowledgments}

The authors thank Mike Heath, Ron Hooks, Matthew Wiggins, Kyle Parris, Neal Roberson, and Harvey Kendrick for their help in this project. The authors gratefully acknowledge statistical advice from Jerry Davis and Xuelin Luo.

\section{Literature Cited}

Beasley, J. P., Jr. 2013. Planting dates. Pages 70-73 in: 2013 Peanut Update. J. P. Beasley, Jr., ed. University of Georgia Cooperative Extension, Athens, GA. Publ. CSS-13-0110.

Branch, W. D. 2007. Registration of 'Georgia-06G' peanut. J. Plant Regist. 1:120. Branch, W. D. 2013. Registration of 'Georgia-12Y' peanut. J. Plant Regist. 7:1-3. Branch, W. D., and Culbreath, A. K. 2013. Yield performance and pest resistance among peanut genotypes when grown without fungicides or insecticides. Crop Prot. 52:22-25.

Brenneman, T. B. 2007. Effects of four commercial peanut seed treatments on plant stand, diseases, and pod yield. (Abstr.) Phytopathology 97:S180.

Brenneman, T. B., Branch, W. D., and Culbreath, A. K. 2014. Comparison of Georgia-06G and Georgia-12Y with seven levels of fungicide inputs. (Abstr.) Proc. Am. Peanut Res. Educ. Soc. 46:51.

Brenneman, T. B., and Hadden, J. F. 1996. Effects of planting date on peanut stem rot development and fungicide efficacy. (Abstr.) Proc. Am. Peanut Res. Educ. Soc. 28:55.
Brown, S. L., Culbreath, A. K., Todd, J. W., Gorbet, D. W., Baldwin, J. A., and Beasley, J. P., Jr. 2005. Development of a method of risk assessment to facilitate integrated management of spotted wilt of peanut. Plant Dis. 89: 348-352.

Brunner, E., Domhof, S., and Langer, F. 2002. Nonparametric Analysis of Longitudinal Data in Factorial Experiments. John Wiley \& Sons, New York.

Cantonwine, E. G., Culbreath, A. K., Shew, B. B., and Boudreau, M. A. 2008 Efficacy of organically acceptable fungicides for management of early and late leaf spot of peanut. Online. Plant Health Prog. doi:10.1094/PHP-20080317-03-RS

Cantonwine, E. G., Holbrook, C. C., Culbreath, A. K., Tubbs, R. S., and Boudreau, M. A. 2011. Genetic and seed treatment effects in organic peanut. Peanut Sci. 38:115-121.

Chiteka, Z. A., Gorbet, D. W., Shokes, F. M., Kucharek, T. A., and Knauft, D. A. 1988. Components of resistance to late leafspot in peanut. I. Levels and variability-implications for selection. Peanut Sci. 15:25-30.

Chu, Y., Wu, C. L., Holbrook, C. C., and Ozias-Akins, P. 2016. Conditions that impact artificial hybridization of Arachis hypogaea L. Peanut Sci. 43:106-115.

Culbreath, A. K., Selph, A. C., Williams, B. W., Kemerait, R. C., Jr., Srinivasan, R., Abney, M. R., Tillman, B. L., Hollbrook, C. C., and Branch, W. D. 2016. Effects of new field resistant cultivars and in-furrow applications of phorate insecticide on tomato spotted wilt of peanut. Crop Prot. 81:70-75.

Culbreath, A. K., and Srinivasan, R. 2011. Epidemiology of spotted wilt disease of peanut caused by Tomato spotted wilt virus in the southeastern U.S. Virus Res. 159:101-109.

Culbreath, A. K., Tillman, B. L., Tubbs, R. S., Beasley, J. P., Jr., Kemerait, R. C., Jr., and Brenneman, T. B. 2010. Interactive effects of planting date and cultivar on tomato spotted wilt of peanut. Plant Dis. 94:898-904

Culbreath, A. K., Todd, J. W., and Brown, S. L. 2003. Epidemiology and management of tomato spotted wilt in peanut. Annu. Rev. Phytopathol. 41:53-75.

Culbreath, A. K., Todd, J. W., Demski, J. W., and Chamberlin, J. R. 1992. Disease progress of spotted wilt in peanut cultivars Florunner and Southern Runner. Phytopathology 82:766-771.

Culbreath, A. K., Todd, J. W., Gorbet, D. W., Shokes, F. M., and Pappu, H. R 1997. Field response of new peanut cultivar UF 91108 to tomato spotted wilt virus. Plant Dis. 81:1410-1415

Fulmer, A. M. 2017. Differentiation, prediction and management of early and late leaf spot of peanut in the southeastern United States and Haiti. Ph.D. thesis. University of Georgia, Athens, GA.

Johnson, W. C., III, and Mullinex, B. G., Jr. 2008. Potential weed management systems for organic peanut production. Peanut Sci. 35:67-72.

Jordan, B. S., Culbreath, A. K., Brenneman, T. B., Kemerait, R. C., and Branch, W. D. 2017. Late leaf spot severity and yield of new peanut breeding lines and cultivars grown without fungicides. Plant Dis. 101:1843-1850.

Kemerait, R., Culbreath, A., Prostko, E., Brenneman, T., Smith, A., Tubbs, S., Srinivasan, R., Abney, M., Monfort, S., Tillman, B., Dufault, N., Rowland, D. Mulvaney, M., Hagan, A., Sarver, J., Anco, D., and Smith, N. 2016. Peanut Rx: Minimizing diseases of peanut in the southeastern United States. Pages 47-62 in: 2016 Peanut Production Update. W. S. Monfort, ed. University of Georgia Cooperative Extension, Athens, GA. Publ. CSS-12-0130.

Norden, A. J., Lipscomb, R. W., and Carver, W. A. 1969. Registration of Florunner peanuts. Crop Sci. 9:850.

Plumblee, M. T., Tubbs, R. S., Prostko, E. P., and Smith, N. B. 2018. Evaluation of seeding rate and cultivar effects on peanut (Arachis hypogaea L.) seeded in 76-cm row spacing. Peanut Sci. 45:32-37.

Prasad, P. V. V., Allen, L. H., Jr., Gorbet, D. W., Boote, K. J., and Thomas, J. M. G. 2006. Influence of soil temperature on seedling emergence and early growth of peanut cultivars in field conditions. J. Agron. Crop Sci. 192:168-177.

Rodriguez-Kabana, R., Backman, P. A., and Williams, J. C. 1975. Determination of yield losses to Sclerotium rolfsii in peanut fields. Plant Dis. Rep. 59:855-858.

Sanden, G. E., Shokes, F. M., and Gorbet, D. W. 1981. Peanut leaf spot control in Florida USA as affected by spray initiation date and planting date. (Abstr.) Proc. Am. Peanut Res. Educ. Soc. 13:95.

Shah, D. A., and Madden, L. V. 2004. Nonparametric analysis of ordinal data in designed factorial experiments. Phytopathology 94:33-43.

Shaner, G., and Finney, R. E. 1977. The effect of nitrogen fertilization on the expression of slow-mildewing resistance in Knox wheat. Phytopathology 67: 1051-1056.

Shokes, F. M., and Culbreath, A. K. 1997. Early and Late Leaf Spots. Pages 17-20 in: Compendium of Peanut Diseases, 2nd ed. N. Kokalis-Burelle, D. M. Porter, R. Rodriguez-Kabana and P. Subrahmanyam, eds. American Phytopathological Society, St. Paul, MN.

Shokes, F. M., Gorbet, D. W., and Sanden, G. E. 1982. Effect of planting date and date of spray initiation on control of peanut leaf spots in Florida. Plant Dis. 66: 574-575.

Tsai, Y. C., and Brenneman, T. B. 2018. Early-season fungicide programs for peanut disease management. Plant Health Prog. 19:103-106.

Tubbs, R. S., Cantonwine, E. G., and Brenneman, T. B. 2013. Efficacy of peanut seed treatments for organic management in Georgia. Peanut Sci. 40:149-155. 